\title{
The Relationship Understanding and Attitudes of Parents for Learning's Achievement Children with Special Needs in Inclusive School
}

\author{
Humairah Wahidah An-Nizzah ${ }^{1}$, Abdul Salim Choiri ${ }^{2}$ \\ ${ }^{1,2}$ Sebelas Maret University, Special Education, Surakarta, Central Java, Indonesia
}

\begin{abstract}
Understanding and attitude of parents in educating children is inseparable. The purpose of this study was to determine the relationship understanding and attitudes of parents for learning's achievement children with special needs in inclusive school. This research using correlation method, data collection technique using questionnaire and test multiple choice. The population in this study were 30 parents of children with special needs in inclusive school. The result of this study shows (1) there is a significant correlation understanding of parents with learning's achievement children with special needs, (2) there is a significant correlation attitude of parents with learning's achievement children with special needs, (3) there is a significant correlation understanding and attitude of parents with learning's achievement children with special needs.
\end{abstract}

Keywords: understanding of parents, attitude of parents, children with special needs, inclusive school, learning achievement

\section{Introduction}

Knowledge is the result of knowing and this occurs after making sense to a particular object, most of human knowledge obtained through the eyes (sight) and ears (hearing). Knowledge of a person is closely related to the behavior to be taken, because with that knowledge we have reason and foundation to determine a choice [1]. Many parents have children with special needs but still have low knowledge about concept inclusion education and children with special needs.

Parents have an important role, obligations and consequences for maintaining, nurturing and educating children in home, school or community environment. Implementation of processes education in there three main environment, in family, school, and in the community, some formally, informally, and some nonformally. These three educational environment by $\mathrm{Ki}$ Hajar Dewantara are called three education centers [2]. The three education centers that gradually and integrally assumes an educational responsibility for the younger generation [3]. In education, the family is the lighthouse of the direction and the willingness of the children educations [4].

The involvement or role of parents in education is an important resource for the success of children in school. Team involvement in workshops, volunteers in class activities, or other opportunities [5]. Team involvement is a significant factor for improving student achievement [6]. There are four factors that influence parental decisions about their involvement in children's with special needs education: (1) an understanding of the importance of parent's role in children's education; (2) Expectations on children with special needs; (3) Perceptions of children's limitations; and (4) Perception of school for children with special needs [7].

The parents should be understand about concepts of inclusive education and children with special needs for the future of children. In other terms the success of children especially education, very dependent on the education provides by his parents in the family environment. If parents are wrong in providing education where not adapted to the abilities and needs of children, this will result in low learning achievement.

The inclusive education is an education that places all learners with special needs in regular schools throughout the day [8]. It is the school must accommodate all children regardless of physical, intellectual, social, emotional, linguistic or other conditions [9]. This include children with disabilities, gifted, street children, children from ethnic minority, linguistic, or cultural populations and children from disadvantaged areas. It is the schools that accommodate all pupils in the same school, with challenging education programs, appropriate but individual needs, where every child is accepted as part of the community so that children can reach success and fulfilled his needs [10].

The learning achievement is a proof of student achievement or ability of a student in doing learning activities in accordance with the weight achieved [11]. It is also the result of interaction between the various factors that influence it both from within the self (internal factors) and from outside (external factors) individuals [12]. The teory of bloom's taxonomy, learning achievement is the result of behavioral change that encompasses three cognitive domains consisting of: knowledge, understanding, application, analysis, synthesis, and evaluation.

There are factors that affect learning achievement include internal factors and external factors are:

1. Internal factors

a. Factor physical include :

(1) Factors health

(2) Disability body

b. Factor psychological includes :
(1) Intelligence
(2) Attention
(3) Interests
(4) Talent

Volume 6 Issue 12, Desember 2017 

(5) Motivation
(6) Maturity
(7) Readiness
c. Factor fatigue

2. External factors

a. Factor family, includes :

(1) ways parents educate

(2) relations between member family

(3) atmosphere home

(4) circumstances economy family

(5) understanding parent

(6) background back culture

b. Factor school covers method teaching, curriculum, relationship teacher with student, relationship students with student, discipline school, tools lesson, time school, standards lesson, circumstances building, method learning, and task home.

c. Factor community covers activities in society, massa media, friends playing, form life socially [13].

Based on the facts above can be seen that the understanding and attitudes of parents to children with special needs in inclusive schools is still lacking, some of which are suspected to be factors that cause low learning achievement of children with special needs.

The purpose of this study is to ; (1) to tknowing a positive relationship between parent's understanding and learning achievement of children with special needs in inclusive school, (2) to knowing a positive relationship between parent's attitudes and learning achievement of children with special needs in inclusive school, (3) to knowing a positive relationship between understanding and attitude of parent for learning achievement of children with special needs in inclusive school.

\section{Methods}

This research using correlational method. It is a research conducted by researchs to determine the level of relationship between two or more variables without making any change, additions or manipulations to existing data [14]. Usefulness of this correlation is to test two significance of two variables, to know the strong weak relationship, and to know the amount of retribution [15]. The variable of this research is understanding and attitude of parents as dependent variable, and learning achievement of children with special needs as independent variable.

Data collection technique can do using test, questionnaire, interview, observation, and documentation [14]. This research using a test, questionnaire and documment. The test technique to collecting understanding data of parent about concept inclusive education and children with special needs, questionnaire to obtain attitude data of parents and docummentation of report student learning outcomes to knowing of learning achievement of children with special needs.
The population is ageneralization area consisting of objects or subjects that have certain qualities and characteristics set by researchers to be studied and then drawn conclusions [16]. The sample is part of the population that is considered to represent the population [17]. The population and sample of this study is 30 parents of children with special needs in inclusive school.

This study is using quantitative data analysis with correlation. This quantitative analysis is expressed in numbers and analyzed with descriptive statistical. It is to determine the frequency and percentage relationship understanding of parents, attitude of parents, and learning achievement of children with special needs. This data is obtained from the scores of questionnaires and test on the answers given by the respondents. Data analysis technique in this study using non parametric statistics.

In this research correlation analysis is used to explain the degree of relationship between independent variables and dependent variables where: "variable that have a values of $r$ $<0.05$ are removed from the modeling gradually. Starting from a variable that has smallest $r$ value one by one". correlation analyis using software appication SPSS version 22.

\section{Results}

Descriptive statistics of this study show mean, std.deviation and N. The mean value of understanding is 69,63 with Std.Deviation is 6,781 . The mean value of attitude is 74,87 with Std.Deviation is 6,152. The mean value of achievement is 79,90 with Std.Deviation is 4,759 with $\mathrm{N}$ is 30 (table 1)

The value of $r$ between the understanding of parents and learning achievement of children with special needs is ,518 with Sig. (2-tailed) is ,003. The value of $r$ between attitude of parents and learning achievement of children with special needs is ,660 with Sig. (2-tailed) is ,000 (Table 2).

The value of $r$ between understanding of parents and attitude of parent with learning achievement of children with special needs is ,605 with Sig. (2-tailed) is ,001. The results are said to have an effect when Sig. (2-tailed) $<0.05$. The results showed that Sig. (2-tailed) was valued at ,001. This means that the understanding of parents and attitude of parent is related to the learning achievement of children with special needs, value of Sig. (2-tailed) is ,001<0,05 (Table 3).

Table 1: Descriptive statistics

\begin{tabular}{|c|c|c|c|}
\hline \multicolumn{4}{|c|}{ Descriptive Statistics } \\
\hline & Mean & Std. Deviation & $\mathrm{N}$ \\
\hline Understanding & 69,63 & 6,871 & 30 \\
\hline Attitude & 74,87 & 6,152 & 30 \\
\hline Achievement & 79,90 & 4,759 & 30 \\
\hline
\end{tabular}


International Journal of Science and Research (IJSR)

ISSN (Online): 2319-7064

Index Copernicus Value (2016): 79.57 | Impact Factor (2015): 6.391

Table 2: Correlation of variable independent

\begin{tabular}{|c|c|c|c|c|}
\hline \multicolumn{5}{|c|}{ Correlations } \\
\hline & & Understanding & Attitude & Achievement \\
\hline \multirow[t]{3}{*}{ Understanding } & Pearson Correlation & 1 &, $731^{* *}$ &, $518^{* *}$ \\
\hline & Sig. (2-tailed) & & ,000 & ,003 \\
\hline & $\mathrm{N}$ & 30 & 30 & 30 \\
\hline \multirow[t]{3}{*}{ Attitude } & Pearson Correlation &, $731^{* * *}$ & 1 &, $660^{\text {*** }}$ \\
\hline & Sig. (2-tailed) & 000 & & 000 \\
\hline & $\mathrm{N}$ & 30 & 30 & 30 \\
\hline \multirow[t]{3}{*}{ Achievement } & Pearson Correlation &, $518^{* * *}$ & $660^{\text {*** }}$ & 1 \\
\hline & Sig. (2-tailed) &, 003 & 000 & \\
\hline & $\mathrm{N}$ & 30 & 30 & 30 \\
\hline
\end{tabular}

Table 3: Correlation understanding of parents and attitude of parent with learning achievement of children with special needs

\begin{tabular}{|c|c|c|c|c|}
\hline \multicolumn{5}{|c|}{ Correlations } \\
\hline \multicolumn{3}{|c|}{ Control Variables } & $\begin{array}{c}\text { Understand } \\
\text { ing }\end{array}$ & Attitude \\
\hline \multirow{6}{*}{ Achievement } & \multirow{3}{*}{$\begin{array}{c}\text { Understand } \\
\text { ing }\end{array}$} & Correlation & 1,000 & ,605 \\
\hline & & $\begin{array}{c}\text { Significance } \\
\text { (2-tailed) }\end{array}$ & . & ,001 \\
\hline & & $\mathrm{df}$ & 0 & 27 \\
\hline & \multirow{3}{*}{ Attitude } & Correlation & ,605 & 1,000 \\
\hline & & $\begin{array}{c}\text { Significance } \\
\text { (2-tailed) }\end{array}$ & ,001 & . \\
\hline & & $\mathrm{df}$ & 27 & 0 \\
\hline
\end{tabular}

\section{Discusion}

This research aims to analyze the understanding of parent and attitude of parent with learning achievement of children with special needs in inclusive school. Research results can be seen from the dependent and independent variable relationships are demonstrated through analysis using correlation test of the outlined as follows:

\subsection{The relationship between understanding of parent and learning achievement of children with special needs in Inclusive School}

The value of $r$ between the understanding of parents and learning achievement of children with special needs is ,518 with Sig. (2-tailed) is ,003. The findings of this study indicated that there was significant relationship understanding of parents with learning achievement of children with special needs.

A collaborative relationship and sharing of knowledge among professionals could improve understanding of their children's difficulties, and cause the children to feel more supported during interventions that would reflect a greater measure of inclusivity.

Parents also receive important attention in assisting their involvement in supporting school programs that have been declared, because based on the understanding of the role as well as active parents very determine the success of the learning program [18].
4.2 The relationship between attitude of parents and the learning achievement of children with special needs in inclusive schools

The value of $r$ between attitude of parents and learning achievement of children with special needs is ,660 with Sig. (2-tailed) is ,000. The findings of this study indicated that there was significant relationship attitude of parents with learning achievement of children with special needs.

This result agreed with the results of the term attitude is defined as "an idea charged with emotion which predisposes a class of actions to a particular class of social situation. When parents do not support inclusion, they might negatively influence a child's attitude and behavior [19]. Negative attitudes of parents toward inclusion may also demotivate teachers to commit themselves to realizing inclusive practice.

To promote more positive attitudes, it seems better to focus on environmental factors that can be changed, or at least influenced, through interventions for instance. An important environmental factor to consider is "direct and indirect experience with individuals with disabilities. Because the parental attitudes are influenced by several factors, such as personal ones like education level [20] and socio-economic status [21].

Research showed that parents with such experience, as well as with inclusion, hold more positive attitudes than those who do not [22].

4.3 The relationship between understanding of parent and the attitude of parents for the learning achievement of children with special needs in inclusive schools

The value of $r$ between understanding of parents and attitude of parent with learning achievement of children with special needs is ,605 with Sig. (2-tailed) is ,001. The findings of this study indicated that there was significant relationship understanding of parents and attitude of parents with learning achievement of children with special needs.

Moreover, we wanted to understand whether direct and indirect experiences with children with disabilities were associated with parents' attitudes. This study attempts to fill in these two gaps of knowledge [23]. This could subsequently nurture parent interactions and constructive parent involvement in the child's learning. They could also advise parents on the benefits of increased involvement in

Volume 6 Issue 12, Desember 2017 


\section{International Journal of Science and Research (IJSR) \\ ISSN (Online): 2319-7064}

Index Copernicus Value (2016): 79.57 | Impact Factor (2015): 6.391

their child's education and school life. Moreover, the educational psychologist could play a pivotal role in breaking down the barriers between the school, the parents, and the other professionals involved in the child's life [24].

Such support may require assisting parents with the daily tasks involved in managing their child, such as implementing routine, effective discipline practices, and homework intervention strategies. Support could also include establishing mothers' sense of confidence in their parenting abilities and implementing coping strategies through, for example, support groups with other mothers experiencing similar difficulties.

Student achievement improved when parents became involved, it was also an important task for us to discover the extent to which these findings would be supported by our own parental involvement program investigation. The students, demonstrated by improved academic achievement [25]. Found that parent involvement was a significant factor in both accelerated and sustained student academic performance [6]. The higher the involvement of parents in the activities that are ejected in the school the higher the success rate [18].

It is known together that primary and first education is in the family, both parents are very responsible for their children including in improving learning achievement or ability of the child.

\section{Conclusion and Recommendations}

Based on the results of data analysis and discussion that has been done in the previous chapter, it can be drawn conclusions as follows: First, there is a significant relationship between the understanding of parents with learning achievement. Secondly, there is a significant relationship between attitude of parents with learning achievement. Third, there is a significant relationship between understanding and attitude of parents with learning's achievement children with special needs.

Parents have an important role to children with special needs, not only in the necessities of life both physically and mentally, but also need to be considered in terms of education, because education is the main thing. Children with special needs can perform activities because of education, children can achieve because of education, and children can be due to the education. If parents are wrong in choosing the right education and less educated, then the result would be less than the maximum.

The understanding and attitude of parents should be used as one of the requirements for helping of children with special needs in learning at home, school, and to be a good predictor of achievement than mere results that can be got by foul means.

For that, parents need to have a proper understanding of children with special needs and inclusive education, so that parents can play a role in children's education by taking a wise and precise step, so parents can help children with special needs in improving learning achievement. And children can compete healthy by developing the talent and ability they have.

\section{References}

[1] Soekidjo Notoatmodjo, Public Health: Science and Art, Rineka Cipta, Jakarta 2007.

[2] Suwarno, General Introduction of Education, Bumi Aksara, Jakarta, 1985.

[3] Maunah, Science Education, Teras Press, Yogyakarta 2009.

[4] Musbikin, Smart to Overcome the Problems of Child Growth, Flash Books, Yogyakarta 2012.

[5] Bailey, Silvern, \& Brabham, "The effects of interactive reading home- work and parent involvement on children's inference responses", Early Childhood Education Journal, 32 (3), pp. 173-178, 2004.

[6] Loucks, "Increasing parent/family involvement: Ten ideas that work," NASSP Bulletin, 76 (543), pp. 19-23, 1992

[7] Hendriani, Acceptance of Families Against Individuals Who Have Mental Backwardness, Study report, (Not Published), Surabaya: psychology faculty of airlangga university, 2006.

[8] Hallahan, P. Daniel,. Exceptional Learners: An Introduction to Special Education, Pearson Education Inc, Boston, 2009.

[9] Tarmansyah, Education Inclusion For All, Departement of National Education, Jakarta, 2007.

[10] Sunardi, Tren in Education Incredible, Dikti Depdikbud, Jakarta, 2005.

[11] Sunarto, H, Development of Learners, Rineka Cipta Jakarta, 1996.

[12] Achmadi \& Supriyanto, Factors Affecting Learning Achievement, Remaja Rosdakarya, Bandung, 1990.

[13] Slameto, Learning and Affecting Factors, Rineka Cipta, Jakarta, 2003.

[14] Arikunto, S., A Practice Approach of Research Procedures, Rineka Cipta, Jakarta, 2010.

[15] Ramadona \& Sihkabuden, "Relationship Level of Parent Education, Tutoring and Level of Intelligence (IQ) with Self-Development Ability for Students of Tunagrahita," P3LB Journal, 1 (2), 158-162, December 2014

[16] Sugiyono, Qualitative Quantitative and R\&D Research Method, Alfabeta, Bandung, 2012.

[17] Hasan, Iqbal, Material Statistics Subject, Bummulyi Aksara Press, Jakarta, 2003.

[18] Fauziyah, "Optimizing Character Education in Al Falah Kindergerten Surabaya through Parenting Club," EJurnal of Educatiom Departemen Surabaya, Vol 1, pp. $1-12,2011$.

[19] De Boer, A. A., Pijl, S. J., Post, W. J., \& Minnaert, A. E. M. G, "Which variables relate to the attitudes of teachers, parents, and peers towards students with special educational needs in regular education," Educational Studies, 38, 433-448, 2012.

[20] Balboni, G., \& Pedrabissi, L, "Attitudes of Italian teachers and parents toward school inclusion of students with mental retardation: The role of experience," Education \& Training in Mental Retardation \& Developmental Disabilities, 35, 148-159, 2000.

\section{Volume 6 Issue 12, Desember 2017}




\section{International Journal of Science and Research (IJSR) \\ ISSN (Online): 2319-7064}

Index Copernicus Value (2016): 79.57 | Impact Factor (2015): 6.391

[21] Tafa, E., \& Manolitsis, G, “Attitudes of Greek parents of typically developing kindergarten children towards inclusive education," European Journal of Special Needs Education, 18, 155-171, 2003.

[22] Kalyva, E., \& Agaliotis, I, "Can contact affect Greek children's understanding of and attitudes towards peers with physical disabilities," European Journal of Special Needs Education, 24, 213-220, 2009. doi:10.1080/08856250902793701

[23] De Bour, A.A., \& Munde, V.S. "Parental Attitudes Toward the Inclusion of Children With Profound Intellectual and Multiple Disabilities in General Primary Education in the Netherlands", The Journal of Special Education Vol. 49(3) 179-187, 2015.

[24] Rogers MA, Weiner J, Marton I \& Tannock R, "Parental involvement in children's learning: comparing parents of children with and without attentiondeficit/hyperactivity disorder (ADHD)", Journal of School Psychology, 47(3):167-185, 2009.

[25] S. R. Hara., D.J. Burke, "Parent Involvement: The Key To Improved Student Achievement", The School Community Journal, Vol. 8, No. 2, Fall/Winter 1998.

\section{Author Profile}

Humairah Wahidah An-Nizzah received the S.Pd. a Bachelor of Special Education degrees from Sebelas Maret University in 2015. From 2015 until now, she studied at the postgraduate major in special education at Sebelas Maret University. She was also shadow teacher in Makarima Kindergarten.

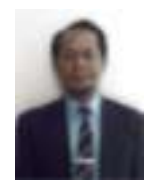

Abdul Salim Choiri receive the Dr and M.Kes, a Master of health education in Public Health Sciences, concentration education from Airlangga University in 1994 and Doctor of Education (Ed.D) in Science Education from Sebelas Maret University in 2013. During 1994-now, he was teaching in Sebelas Maret University as lecture of special education. 